\title{
Influence of orocaecal transit time on hydrogen excretion after carbohydrate malabsorption
}

\author{
J J RUMESSEN, O HAMBERG, AND E GUDMAND-HØYER \\ From the Department of Gastroenterology and Internal Medicine F, Gentofte Hospital, University of \\ Copenhagen, DK-2900 Hellerup, Denmark
}

SUMMARY The aim of the present study was to determine whether changes in orocaecal transit time (OCTT) affect the magnitude of the breath hydrogen $\left(\mathrm{H}_{2}\right)$ excretion after ingestion of unabsorbable carbohydrate. We studied eight healthy subjects by interval sampling of end expiratory $\mathrm{H}_{2}$ concentration for 12 hours after ingestion of: (1) $10 \mathrm{~g}$ lactulose (L); (2) $10 \mathrm{~g}$ L with $20 \mathrm{mg}$ metoclopramide (M) as tablets; (3) $20 \mathrm{~g} \mathrm{~L}$, and (4) $20 \mathrm{~g} \mathrm{~L}$ with $7.5 \mathrm{mg}$ diphenoxylate (D) as tablets, in random order. In spite of significant changes in OCTT after $M$ and $D$, there were no significant changes, compared for the same dose of lactulose, with respect to area under the breath $\mathrm{H}_{2}$ excretion curves, peak increments of $\mathrm{H}_{2}$ concentration or timing of the peak increment. We conclude that, within the ranges observed, the OCTT does not significantly affect the shape of the $\mathrm{H}_{2}$ concentration versus time curves. In comparative studies estimates of the degree of carbohydrate malabsorption on the basis of breath $\mathrm{H}_{2}$ concentration may be valid in spite of differences in OCTT.

Breath hydrogen $\left(\mathrm{H}_{2}\right)$ tests in the form of interval sampling of end expiratory $\mathrm{H}_{2}$ concentrations are widely used in studies of carbohydrate absorption. Quantitative estimates of the amount of carbohydrate malabsorbed from a given test meal is generally obtained by comparing the areas under the breath $\mathrm{H}_{2}$ excretion curves after different meals or by comparing with the area obtained after a given dose of the non-absorbable disaccharide lactulose..$^{1-6}$ This procedure implies that extrapolation of data from the more simple interval sampling of $\mathrm{H}_{2}$ concentrations ${ }^{7}$ to quantitative measurements of total $\mathrm{H}_{2}$ excretion $^{8}$ is valid. It has been suggested that quantitative estimates of carbohydrate malabsorption are valid on the basis of breath $\mathrm{H}_{2}$ concentration only if it is assumed that the colonic entry rate of the test carbohydrate and lactulose is equivalent. ${ }^{9}$ This suggestion could challenge the validity of quantitative estimates of carbohydrate malabsorption when significant differences of the orocaecal transit times between different test meals exist. The relationship between upper intestinal transit per se, however, and colonic $\mathrm{H}_{2}$ production is not known. We have therefore investi-

Address for correspondence: Dr J J Rumessen, Dept of Gastroenterology and Internal Medicine F, Gentofte Hospital, DK-2900, Hellerup, Denmark

Accepted for publication 31 October 1988. gated the effect of pharmacologically induced changes in orocaecal transit time on the $\mathrm{H}_{2}$ excretion as measured by interval sampling of end expiratory breath $\mathrm{H}_{2}$ concentrations after different loads of lactulose.

\section{Methods}

SUBJECTS

Eight healthy adults (seven men and one woman, aged 21-33 years) were studied. The subjects were taking no other medication including antibiotics, salicylates and laxatives, they had no history of recurrent or present chronic gastrointestinal or pulmonary disease. No subjects had lactose intolerance. All subjects were $\mathrm{H}_{2}$ producers $(\geq 10 \mathrm{ppm}$ sustained rise of $\mathrm{H}_{2}$ concentration after $10 \mathrm{~g}$ lactulose with $100 \mathrm{ml}$ tap water). Blood screening tests were normal.

\section{BREATH TESTS}

Breath $\mathrm{H}_{2}$ excretion was measured by interval sampling of end expiratory $\mathrm{H}_{2}$ concentrations on a GMI (Gas Measurements Instruments Ltd, Renfrew, Scotland) $\mathrm{H}_{2}$ monitor. ${ }^{10}$ After at least 12 hours overnight fast, the subjects had a mouth rinse 811 
thereafter repeated, and ended with a tap water swill. ${ }^{11}{ }^{12} \mathrm{In}$ all breath tests end expiratory $\mathrm{H}_{2}$ concentrations were collected in duplicate from the mouth in $20 \mathrm{ml}$ plastic syringes $\left(\mathrm{Once}^{\mathrm{R}}\right)$ fitted with a Y-piece. Samples were taken before lactulose ingestion and every 15 minutes for seven hours and immediately analysed. The study was extended to 12 hours, and during the last five hours samples were taken every 30 minutes in Becton-Dickinson ${ }^{\mathrm{R}} 20 \mathrm{ml}$ plastic syringes, which were stored overnight at $5^{\circ} \mathrm{C}$ for analysis the next morning. ${ }^{13}$ Smoking and sleeping was not allowed and the subjects were non-ambulant. During the study period and for the 24 hours after each test the subjects completed a standardised symptom score. ${ }^{4}$

\section{DESIGN OF THE STUDY}

All breath tests were carried out within a period of two months and were coordinated with a separate study of quantifying carbohydrate malabsorption (Rumessen et al, in preparation). A minimum of six days elapsed between the difference tests to avoid colonic bacterial metabolic changes. ${ }^{14}$ is All subjects initially received $10 \mathrm{~g}(15 \mathrm{ml})$ lactulose (SAD) in 100 $\mathrm{ml}$ water. The lactulose solution contained $667 \mathrm{mg}$ lactulose, $60 \mathrm{mg}$ lactose, and $110 \mathrm{mg}$ galactose per $\mathrm{ml}$ (according to the supplier). Subsequently the following tests were performed in random order: (1) $10 \mathrm{~g}$ lactulose in $100 \mathrm{ml}$ water; (2) $10 \mathrm{~g}$ lactulose in $100 \mathrm{ml}$ water and $20 \mathrm{mg}$ metoclopramide (Primperan ${ }^{R}$ ) as tablets 45 minutes before the test solution. Each tablet of $10 \mathrm{mg}$ contained $34 \mathrm{mg}$ lactose (according to the supplier); (3) $20 \mathrm{~g}$ lactulose in $200 \mathrm{ml}$ water;

Table Hydrogen excretion after changes of orocaecal transit time (OCTT) of different lactulose $(L)$ loads with 20 mg metoclopramide $(M)$ or $7.5 \mathrm{mg}$ diphenoxylate $(D)$ in eight subjects

\begin{tabular}{|c|c|c|c|c|}
\hline & $\begin{array}{l}\text { OCTT } \\
(\mathrm{min})\end{array}$ & $\begin{array}{l}A U C \S \\
\left(p p m \times \min \times 10^{-2}\right)\end{array}$ & $\begin{array}{l}\text { Peak- } \mathrm{H}_{2} \S \\
(\text { ppm })\end{array}$ & $\begin{array}{l}t-p e a k \S \\
(\text { min })\end{array}$ \\
\hline $10 \mathrm{~g} \mathrm{~L}$ & $\begin{array}{l}90^{*} \\
(68-150) \ddagger\end{array}$ & $\begin{array}{l}125 \\
(91-164)\end{array}$ & $\begin{array}{l}60 \\
(41-68)\end{array}$ & $\begin{array}{l}75 \\
(45-90)\end{array}$ \\
\hline $10 \mathrm{~g} \mathrm{~L}+\mathrm{M}$ & $\begin{array}{l}45^{*} \\
(30-56)\end{array}$ & $\begin{array}{l}106 \\
(56-178)\end{array}$ & $\begin{array}{l}44 \\
(30-66)\end{array}$ & $\begin{array}{l}128 \\
(38-214)\end{array}$ \\
\hline $20 \mathrm{~g} \mathrm{~L}$ & $\begin{array}{c}60 \dagger \ddagger \\
(15-75)\end{array}$ & $\begin{array}{l}243 \\
(182-334)\end{array}$ & $\begin{array}{l}78 \\
(56-126)\end{array}$ & $\begin{array}{l}150 \\
(90-206)\end{array}$ \\
\hline $20 \mathrm{~g} \mathrm{~L}+\mathrm{D}$ & $\begin{array}{l}75 \dagger \\
(45-105)\end{array}$ & $\begin{array}{l}187 \\
(137-345)\end{array}$ & $\begin{array}{l}73 \\
(60-93)\end{array}$ & $\begin{array}{l}143 \\
(75-214)\end{array}$ \\
\hline
\end{tabular}

*The OCTT was significantly shorter after $M(p<0 \cdot 01)$; $†$ The OCTT was significantly longer after $D(p<0.05)$; $\ddagger$ The OCTT of $10 \mathrm{~g} \mathrm{~L}$ was significantly longer compared with $20 \mathrm{~g} \mathrm{~L}(\mathrm{p}<0.05)$; §For the same lactulose loads there were no significant differences $(p>0 \cdot 10)$

AUC: Area under the $\mathrm{H}_{2}$ excretion curve from OCTT to 12 hours minus area under lowest previous value in the same period.

Peak- $\mathrm{H}_{2}$ : Maximal rise of $\mathrm{H}_{2}$ concentration during study period. t-peak: Time from OCTT to peak- $\mathrm{H}_{2}$.

Results are given as medians (interquartile ranges).
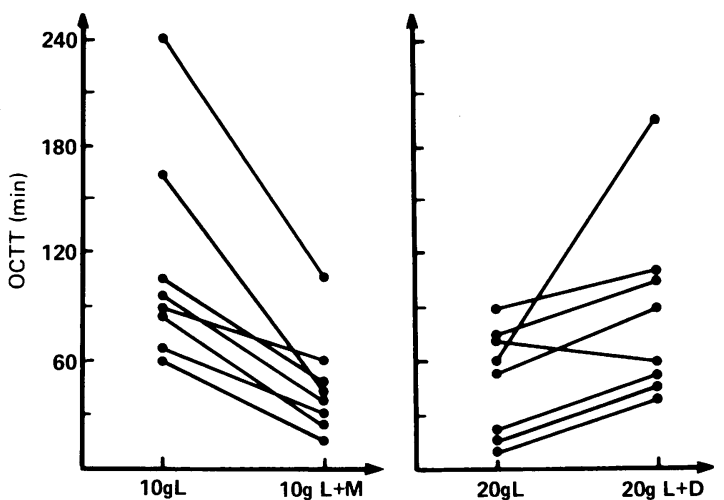

Figure Effect of $20 \mathrm{mg}$ metoclopramide $(M)$ and $7.5 \mathrm{mg}$ diphenoxylate $(D)$ as tablets on the orocaecal transit times (OCTT) of different doses of lactulose $(L)(p<0 \cdot 01(M)$, $p<0.05(D))$.

(4) $20 \mathrm{~g}$ lactulose in $200 \mathrm{ml}$ water and $7.5 \mathrm{~g}$ diphenoxylate $\left(\right.$ Retardin $\left.^{\mathrm{R}}\right)$ as tablets, 45 minutes before the test solution. Each tablet of $2.5 \mathrm{mg}$ contained 25 microgram atropine and $145 \mathrm{mg}$ lactose (according to the supplier); (5) Fasting except for tap water without restrictions. During the course of all tests (incl no 5) a standardised meal consisting of $100 \mathrm{~g}$ minced meat stew together with $50 \mathrm{~g}$ boiled rice and $150 \mathrm{ml}$ tap water was given within four hours, but never before the orocaecal transit time was determined. The meal was consumed within a period of 15 minutes.

This meal caused no significant $\mathrm{H}_{2}$ production neither at ingestion nor during the rest of the study period (Rumessen et al, in preparation).

\section{CALCULATIONS AND STATISTICS}

The following variables were determined and compared for the same dose of lactulose: (1) Orocaecal transit time (OCTT), as the interval between ingestion and the initial sustained rise in breath $\mathrm{H}_{2}$ concentration of $10 \mathrm{ppm}$ or more $;{ }^{16}$ (2) Maximal rise of $\mathrm{H}_{2}$ concentration from lowest previous values (peak- $\mathrm{H}_{2}$ ); (3) Time in minutes from OCTT to peak $\mathrm{H}_{2}$ (t-peak); (4) Area under the $\mathrm{H}_{2}$ concentration versus time curves from the OCTT according to the trapezoidal rule (AUC). AUC's were calculated as: (a) Area under the curve minus area under the lowest previous values; (b) Area under the curve minus area under each individual fasting curve.

These areas were calculated for the first two and four hours of the sustained increase in $\mathrm{H}_{2}$ concentration as well as for the whole period from OCTT to 12 hours. Baseline $\mathrm{H}_{2}$ concentrations were not reached in two subjects after $20 \mathrm{~g}$ lactulose and in two others after $20 \mathrm{~g}$ lactulose + diphenoxylate. The small additional areas were calculated by extrapolation to base line. 
We furthermore compared the OCTT of $10 \mathrm{~g}$ lactulose with that of $20 \mathrm{~g}$ lactulose. The reproducibility of the initial $10 \mathrm{~g}$ lactulose load and the $10 \mathrm{~g}$ load used for calculation and comparison is reported elsewhere (Rumessen $e t$ al, in preparation).

STATISTICAL ANALYSIS

We used non-parametric statistics (Pratt's test, Spearmans rank correlation analysis), and the results were consequently expressed as medians and interquartile ranges. $p<0.05$ was considered significant.

\section{ETHICS}

The study was carried out in accordance with the Helsinki Declaration II, and the study protocol was approved by the Copenhagen County medical ethics committee.

\section{Results}

Our results are summarised in the Table.

A significant shortening of OCTT was observed after metoclopramide $(\mathrm{p}<0 \cdot 01)$ and OCTT's were significantly increased after diphenoxylate $(0.01<p<0.05)$ (Figure, Table). The difference in OCTT between $10 \mathrm{~g}$ lactulose and $20 \mathrm{~g}$ lactulose was significant $(0.01<\mathrm{p}<0.05)$ (Table). Irrespective of method of calculation, for the same dose of lactulose the changes in AUC's or peak- $\mathrm{H}_{\mathbf{2}}$ when metoclopramide or diphenoxylate was given were not significant $(p>0 \cdot 10)$. There was, however, a tendency towards lower $\mathbf{H}_{2}$ excretion after diphenoxylate (Table). Similarly, there were no significant changes in timing of the peak $-\mathrm{H}_{2}$ value when metoclopramide or diphenoxylate was given $(p>0 \cdot 10)$ (Table). Irrespective of whether metoclopramide or diphenoxylate was taken, there was no overall correlation between OCTT and $\mathrm{H}_{2}$ production for each dose of lactulose $(p>0 \cdot 50)$. The AUC's and $\mathrm{H}_{2}$-peaks of the initial $10 \mathrm{~g}$ lactulose load and the $10 \mathrm{~g}$ lactulose load used for randomised comparison were not significantly different $(p>0 \cdot 10)$, and indicated no change of the overall $\mathbf{H}_{2}$-excretion pattern during the study. Apart from one subject complaining of moderate borborygmia after $20 \mathrm{~g}$ lactulose, the gastrointestinal symptoms were scored as none or mild in all studies with no differences between the test meals. No adverse drug reactions were noted.

\section{Discussion}

The present findings indicate that significant changes of the OCTT do not significantly influence the $\mathrm{H}_{2}$ excretion as measured by interval sampling of end expiratory $\mathrm{H}_{2}$ concentrations after different lactulose loads. There were no indications of changes in the overall $\mathrm{H}_{2}$ excretion pattern during the study period, and the results are not likely to be explained by colonic adaptation or other period effects. There is no evidence suggesting an effect of metoclopramide or diphenoxylate/atropine on colonic bacterial metabolism and metoclopramide seems to have little effect on motility of the large intestine. ${ }^{17}$ The lactose content of the tablets was negligible and irrelevant. Although the material is small and the data show rather large variation, it seems justified to conclude that the OCTT per se, within the ranges observed, does not significantly influence the overall pattern of $\mathrm{H}_{2}$ excretion. Quantitative estimates of carbohydrate malabsorption, whether expressed as AUC's or peak increments of $\mathrm{H}_{2}$ production, may therefore be widely independent of the OCTT's of the substances compared. There was, however, a tendency towards lower $\mathrm{H}_{2}$ excretion after diphenoxylate, but no tendencies were apparent after metoclopramide, although this substance had the greatest effect on OCTT. We cannot, however, exclude the possibility that more extreme differences in transit times may unmask an influence on $\mathrm{H}_{2}$ excretion in a larger sample size, and it is not possible to control all conceivable confounding factors in a study like this.

It is essential for the validity of breath $\mathbf{H}_{2}$ tests that the $\mathrm{H}_{2}$ response to a given load of malabsorbed carbohydrate is rather insensitive to changes of the OCTT within physiological ranges. This is so because: (1) One of the main determinants of OCTT is indeed the malabsorbed amount of carbohydrate itself. ${ }^{18}$ This is illustrated in the present study by the significantly shorter transit times of $20 \mathrm{~g}$ lactulose loads compared with $10 \mathrm{~g}$ doses. This confirms earlier findings, ${ }^{16}{ }^{18}$ and was indeed the reason why we used different doses of lactulose for metoclopramide and diphenoxylate to exert their effects upon. If, therefore, breath $\mathrm{H}_{2}$ tests were very sensitive to changes in transit time, quantitative estimates of malabsorbed carbohydrate would be inherently uninterpretable; (2) If a non-absorbable sugar such as lactulose is used for comparison, the interpretation of the $\mathrm{H}_{2}$ evolution following more complex meals or sugars (as - for example, starch) would be invalid because of the generally more prolonged orocaecal transit times of the latter. ${ }^{18}$

The influence of the OCTT per se on the $\mathrm{H}_{2}$ excretion subsequent to carbohydrate malabsorption has, however, not been studied earlier.

It has been observed that delayed gastric emptying of lactulose due to addition of glucose does not affect the AUC's of the corresponding $\mathrm{H}_{2}$ excretion curves. ${ }^{19}$ The effect of both metoclopramide and diphenoxylate on OCTT as observed by us is probably mainly on small intestinal transit..$^{202}$ Our results are not necessarily in conflict with the findings of 
Read et al" that different colonic entry rates of carbohydrate may affect the timing and the magnitude of the peak $\mathrm{H}_{2}$ production. It was shown ${ }^{9}$ that fast colonic infusion of lactulose produced a greater $\mathrm{H}_{2}$ response than slow infusion of the same dose. However, the difference in infusion rates used $(7 \cdot 5$ times) was rather great, and AUC's were not compared. Furthermore, the OCTT's and the colonic entry rates of malabsorbed carbohydrate are not necessarily correlated, ${ }^{22}$ and it is conceivable that substances with greatly different ileal emptying rates may provoke different $\mathrm{H}_{2}$ responses. In a recent study, ${ }^{23}$ however, a good correspondence was found between the $\mathrm{H}_{2}$ production produced by ingestion of lactulose and infusion of starch.

Breath $\mathrm{H}_{2}$ tests have been used to investigate the effect of drugs on upper intestinal transit. ${ }^{24} 25$ The present study confirms earlier observations supporting the validity of using breath $\mathrm{H}_{2}$ tests for this purpose ${ }^{26}$ Our findings may furthermore support the use of breath $\mathrm{H}_{2}$ tests for evaluation of drugs influencing both intestinal absorption and upper intestinal transit time.

The authors thank Isa Staack, Gitte Bischoff, and Lotte M Hansen for skilful technical assistance, and Lene Krogh for secretarial help.

\section{References}

1 Anderson IH, Levine AS, Levitt MD. Incomplete absorption of the carbohydrate in all-purpose wheat flour. N Engl J Med 1981; 304: 891-2.

2 Kolars JC, Levitt MD, Aouji M, Saviano DA. Yogurt and autodigesting source of lactose. N Engl J Med 1984; 310: $1-3$.

3 Thornton JR, Dryden A, Kelleher J, Losowsky MS. Does super efficient starch absorption promote diverticular disease? $\mathrm{Br}$ Med J 1986; 292: 1708-10.

4 Rumessen JJ, Gudmand-Høyer E. Absorption capacity of fructose in healthy adults. Comparison with sucrose and its constituent monosaccharides. Gut 1986; 27: 1161-8

5 Levitt MD, Hirsh P, Fetzer CA, Sheahan M, Levine AS. $\mathrm{H}_{2}$ excretion after ingestion of complex carbohydrates. Gastroenterology 1987; 92: 383-9.

6 Harms H-K, Bertele-Harms R-M. Bruer-Kleis TA. Enzyme substitution therapy with the yeast Saccharomyces cerevisiae in congenital sucrase-isomaltase deficiency. N Engl J Med 1987; 316: 1306-9.

7 Metz G, Jenkins DJA, Peters TJ, Newman A, Blendis LM. Breath hydrogen as a diagnostic method for hypolactasia. Lancet 1975; i: 1155-7.

8 Bond JH, Levitt MD. Use of pulmonary hydrogen $\left(\mathrm{H}_{2}\right)$ measurements to quantitate carbohydrate absorption. Study of partially gastrectomized patients. J Clin Invest 1972; 51: 1219-25.

9 Read NW, AL-Janabi MN, Bates TE, et al. Interpretation of the breath hydrogen profile obtained after ingesting a solid meal containing unabsorbable carbohydrate. Gut 1985; 26: 834-42.
10 Rumessen JJ, Kokholm G, Gudmand-Høyer E. Methodological aspects of breath hydrogen $\left(\mathrm{H}_{2}\right)$ analysis. Evaluation of a $\mathbf{H}_{2}$ monitor and interpretation of the breath $\mathrm{H}_{2}$ test. Scand J Clin Lab Invest 1987; 47: 555-60.

11 Thompson DG, O'Brien JD, Hardie JM. Influence of the oropharyngeal microflora on the measurement of exhaled breath hydrogen. Gastroenterology 1986; 91: 853-60.

12 Mastropaolo G, Rees WDW. Evaluation of the hydrogen breath test in man: definition and elimination of the early hydrogen peak. Gut 1987; 28: 721-5.

13 Rumessen JJ, Gudmand-Høyer E. Retention and variability of hydrogen $\left(\mathrm{H}_{2}\right)$ samples stored in plastic syringes. Scand J Clin Lab Invest 1987; 47: 627-30.

14 Perman JA, Modler S, Olson AS. Role of $\mathrm{pH}$ in production of hydrogen from carbohydrates by colonic bacterial flora. Studies in vivo and in vitro. J Clin Invest 1981; 67: 643-50.

15 Florent C, Flourie B, Leblond A, Rautureau M, Bernier J-J, Rambaud J-C. Influence of chronic lactulose ingestion on the colonic metabolism of lactulose in man (an in vivo study). J Clin Invest 1985; 75: 608-13.

16 Bond $\mathrm{JH}$, Levitt MD. Investigation of small bowel transit time in man utilizing pulmonary hydrogen $\left(\mathrm{H}_{2}\right)$ measurements. J Lab Clin Med 1975; 85: 546-55.

17 Schultze-Delrieu K. Metoclopramide. Gastroenterology 1979; 77: 768-79.

18 Read NW, Miles CA, Fisher D, et al. Transit of a meal through the stomach, small intestine, and colon in normal subjects and its role in the pathogenesis of diarrhea. Gastroenterology 1980; 79: 1276-82.

19 Rosado JL, Deodhar AD, Bourges H, Solomons NW. The effect of the digestion products of lactose (glucose and galactose) on its intraintestinal, in vivo hydrolysis by exogeneous microbial Beta-D-Galactosidase. J Am Coll Nutr 1986; 5: 281-90.

20 Holgate AM, Read NW. Metoclopramide reduces carbohydrate absorption in man. Br J Clin Pharmacol 1985; 19: 67-72.

21 Nilsson F, Johansson $\mathrm{H}$. A double isotope technique for the evaluation of drug action on gastric evacuation and small bowel propulsion studied in the rat. Gut 1973; 14: 475-7.

22 Phillips SF, Quigley EMM, Kumar D, Kamath PS. Motility of the ileocolonic junction. Gut 1988; 29: 390406.

23 Flourié B, Florent C, Etanchaud F, Edvard D, Franchisseur C, Rambaud J-C. Starch absorption by healthy man evaluated by lactulose hydrogen breath test. Am J Clin Nutr 1988; 47: 61-6.

24 Basilisco G, Bozzani A, Camboni G, et al. Effect of loperamide and naloxone on mouth-to-caecum transit time evaluated by lactulose hydrogen breath test. Gut 1985; 26: 700-3.

25 O'Brien JD, Thompson DG, McIntyre A, Burnham WR, Walker E. Effect of codeine and loperamide on upper intestinal transit and absorption in normal subjects and patients with postvagotomy diarrhoea. Gut 1988; 29: 312-8.

26 Van Wyk M, Sommers K, Steyn GW. Evaluation of gastrointestinal motility using the hydrogen breath test. Br J Clin Pharmacol 1985; 20: 479-81. 